\title{
Traumatismo renal severo con tratamiento conservador
}

A. de Pablo Cárdenas, M.A. Pinós Paul, J.I. Jiménez Aristu*, J. Iriarte Aristu*, L. Garrón Aoiz*, J.A. Millán Serrano*.

Servicios de Urología. Hospital Virgen del Camino. Pamplona (Navarra). *Hospital Reina Sofía. Tudela (Navarra).

Actas Urol Esp 2005; 29 (4): 436

$\mathrm{V}$ arón de 22 años. Traumatismo lumbar izquierdo por caída al suelo mientras jugaba al fútbol, golpeándose con una piedra en el flanco.

Acude a urgencias, deambulando y hemodinámicamente estable, por micción hematúrica. No refiere antecedentes urológicos de interés.

En la TAC abdominopélvica se aprecia un estallido-fragmentación renal izquierdo, con sistema colector y pedículo vascular indemnes; hematoma perirenal (Figs. 1, 2 y 3).

Se instaura actitud expectante, siendo preciso exclusivamente durante su ingreso la transfusión de 4 concentrados de hematies para reposición del hematocrito.

Al año del traumatismo, tras el tratamiento conservador, la TAC pone en evidencia una lesión cicatricial residual en el polo superior y la región posterior del riñón izquierdo, sin ningún otro tipo de alteración (Figs. 4, 5 y 6).

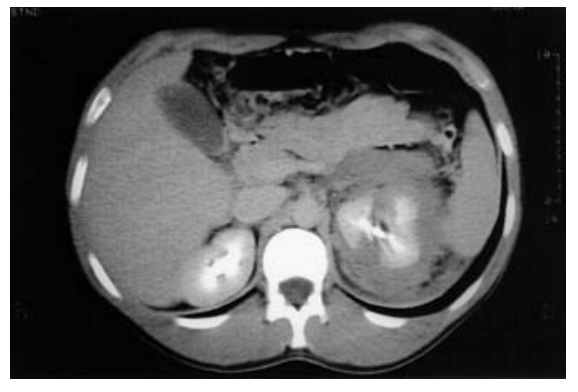

FIGURA 1

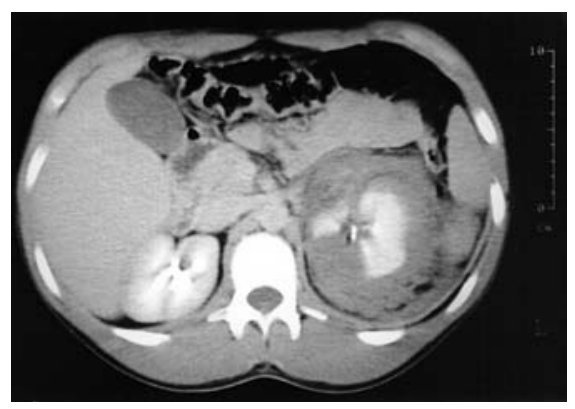

FIGURA 2

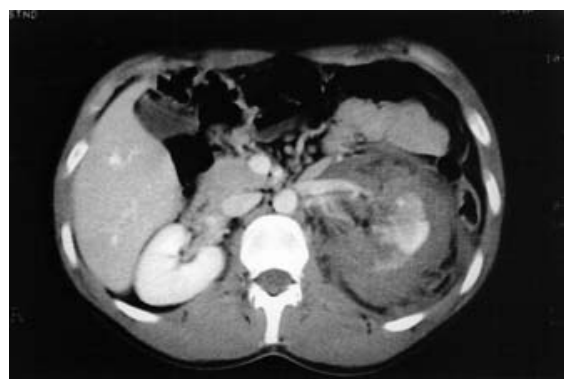

FIGURA 3

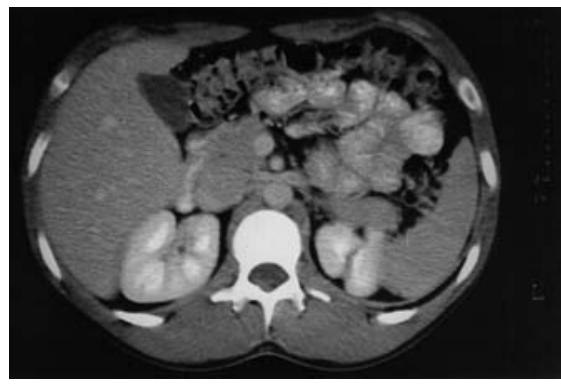

FIGURA 4

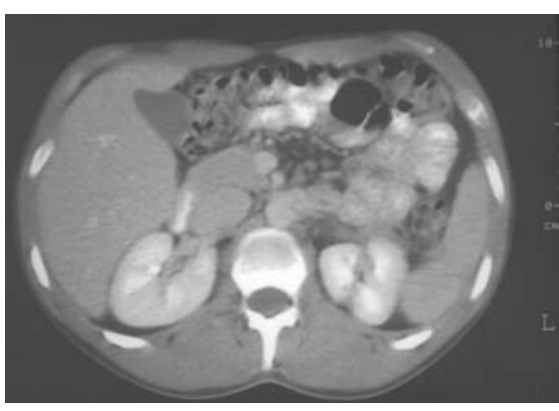

FIGURA 5

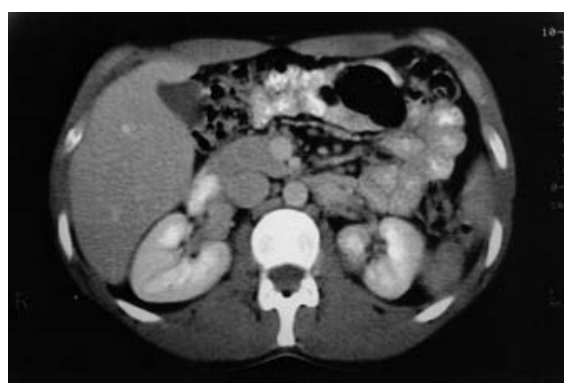

FIGURA 6 